ECOLOGICA, Vol. 28, No 102 (2021), 229-235

https://doi.org/10.18485/ecologica.2021.28.102.13

Scientific paper

UDC: 502/504:[616.98:578.834]

\title{
Positive impact of COVID-19 on environment due to the reduction of tourist movement
}

\section{Pozitivan uticaj COVID-19 na životnu sredinu usled smanjenja turističkih kretanja}

\author{
Živana Krejić ${ }^{1}$, Maja Anđelković ${ }^{2 *}$, Jelena Palić ${ }^{3}$ \\ 1,2,3Union University, Faculty of Business Studies and Law, Belgrade, Serbia / \\ Univerzitet Union, Fakultet za poslovne studije i pravo, Beograd \\ *Corresponding author / Autor za prepisku
}

Received / Rad primljen: 16.12.2020, Accepted / Rad prihvaćen: 10.05.2021.

\begin{abstract}
Due to a significant drop in tourist demand, limited movement of people, closing the borders of many states, airlines began to cancel and reduce the number of flights, and the frequency of land traffic is also significantly reduced. The closure of hotels, travel agencies, and catering facilities has caused great economic damage to cities, countries and companies around the world, from which the recovery process will be extremely long. However, a comparative analysis of studies and reports during the period of COVID-19, in the period from February to June 2020, the positive impact of the pandemic on the environment and sustainable development has been noticed. In countries such as China, Italy, Serbia, the improvement and quality of the air is dominant, as well as water, flora and fauna, that are recovering from pollution. The quantities of waste, excessive hunting and fishing, and disturbance of nature's harmony have been reduced.

The crisis caused by the COVID-19 pandemic is an opportunity for critical reflection in terms of the positive impact that the pandemic has had on the preservation of the environment, which is one of the main tasks of sustainable development.
\end{abstract}

Keywords: COVID-19, environment, pandemic, positive effects, travel.

Sažetak: Usled velikog pada turističke tražnje, ograničenog kretanja ljudi, zatvaranja granica mnogih država, aviokompanije su počele da ukidaju i smanjuju broj letova, a takođe je i frekvencija kopnenog saobraćaja značajno smanjena. Zatvaranje hotela, turističkih agencija i ugostiteljskih objekata donelo je veliku ekonomsku štetu gradovima, zemljama i kompanijama širom sveta, od koje će proces oporavka biti izuzetno dug. Međutim, uporednom analizom studija i izveštaja tokom perioda COVID-19, u periodu od februara do juna 2020. godine, primećen je pozitivan uticaj pandemije na životnu sredinu i održivi razvoj. U zemljama poput Kine, Italije, Srbije evidentno je poboljšanje kvaliteta vazduha, vode, očuvanosti flore i faune koje se oporavljaju od zagađenja. Smanjene su količine otpada, prekomerni lov i ribolov i narušavanje harmonije u prirodnim sistemima.

Kriza izazvana pandemijom COVID-19 prilika je za kritičko promišljanje u smislu pozitivnog uticaja koji je pandemija imala na očuvanje životne sredine, što je jedan od glavnih zadataka održivog razvoja.

Ključne reči: COVID-19, životna sredina, pandemija, pozitivni efekti, putovanja.

\footnotetext{
${ }^{1}$ orcid.org/0000-0003-2490-5755, e-mail: zivana.krejic@fpsp.edu.rs

${ }^{2}$ orcid.org/0000-0002-5507-9831, e-mail: maja.andjelkovic@fpsp.edu.rs

${ }^{3}$ orcid.org/0000-0002-0436-4464, e-mail: jelena.palic@fpsp.edu.rs
} 


\section{INTRODUCTION}

The COVID-19 pandemic is considered as the most crucial global health calamity of the century and the greatest challenge that the humankind faced since the 2nd World War. In December 2019, a new infectious respiratory disease emerged in Wuhan, Hubei province, China and was named by the World Health Organization as COVID-19 (Chakraborty \& Maity, 2020).

The new coronavirus (SARS-CoV2) has generated an unprecedented impact in most countries of the world. The virus has affected almost every country on the planet (213 in total), spread to more than 2 million people, and caused around 130,000 deaths (Carr, 2020; WHO, 2020; ZambranoMonserrate, Ruano \& Sanchez-Alcalde, 2020). The sectors of the economies of countries around the world are feeling the negative consequences of the coronavirus, which have occurred primarily due to isolation, reduction of human movement, and thus reduction of the process of production and sale of products, and also provision of services. One of the sectors hardest hit in the world is tourism. The United Nations World Tourism Organization (UNWTO, 2020) reported that "the worldwide outbreak of COVID-19 has brought the world to a standstill", and claimed that "tourism has been the worst affected of all major economic sectors".

With the spread of the Coronavirus in the country, the tourism industry got highly impacted. The people are ordered to stay home to safeguard themselves from the virus. This has created a major downfall in the tourism industry from domestic as well as international perspectives (Springer, 2020; Han, 2019). There are many domestic as well as international flights, which forced to be canceled because of the panic related to the emergence of Corona Virus. The airline industry is severely affected due to the cancellation of the flights from and to china due to coronavirus. Cancellations of flights have severely impacted the industry, as the sales and revenue of the Airlines Company have been reduced significantly. Furthermore, many cruise lines like Norwegian Cruise Line and Royal Caribbean have suspended sailing from and to China. Since the outbreak has begun the Cruise lines have limited passengers. The hotels, airlines as well as the cruise operations were stopped (Hoque et al., 2020; World Economic Forum, 2020).

However, despite the numerous negative consequences that the COVID-19 pandemic had on the tourism industry, there are also positive effects that have arisen as a result of the reduction of tourist movements. The aim of this paper is to point out examples from practice that indicate the positive effects of a pandemic, when it comes to sustainable development and the environment. Tourism is an economic branch that is most susceptible to the impact of all forms of crises: natural disasters, wars, terrorist attacks, economic instability, pandemics. All forms of crisis have a negative impact on tourism and its development (Pappas \& Apostolakis, 2020; Wang et al., 2018, Kapiki, 2012). Natural disasters, such as earthquakes, tsunamis, volcano eruptions etc., have been historically causing disastrous impact on the lives of people (Genç, 2018, 87). As in all economic activities, tourism sector and touristic destinations are vulnerable to natural disasters, the intensity of which has been rapidly increasing (Walters et. al., 2015, 101). Economic revenues that a destination receives decrease sharply parallel to the decrease in the number of tourist arrivals, hence the damage that the location gets from natural disaster deepens even further. In other words, travel decisions are made by taking the possible risks into consideration. Natural disasters affect international tourist arrivals negatively (Barbhuiya \& Chatterjee, 2020; Genç, 2018; Tsai et al., 2016). When natural disasters strike, negative ramifications can be overwhelming, particularly to destination image (Bauman, Yuan \& Williams, 2019).

The recent World Travel and Tourism Council (2019) report on peace and tourism highlights the industry's recognition of the important nexus between tourism and peace. The negative impacts of conflict on tourism are far reaching and result from reductions in tourist arrivals, which is either related to tourists' perceptions of safety and risk, and negative travel advisories, or directly to the loss of tourist attractions and infrastructure (Lepp, Gibson \& Lane, 2011). Conflict in the wider region is also problematic as seen in Jordan which reportedly suffers from conflict in neighbouring Syria (Becken \& Carmignani, 2016). Wars are the most common form of crisis and have had a very bad effect on the general development of the area, as well as on the development of the travel industry in today's Serbia (Krejić, Čerović \& Milićević, 2017). The country's history, which is shadowed by war, political instability and acts of terrorism, has caused the country to be perceived as an undesirable vacation destination (Harb, 2016). One example of the very bad impact of the war on the development of tourism in Sri Lanka is the civil war that lasted for almost three decades (Fernando, 2017).

Terrorism has become one of the greatest problems of humanity today. The methods of terrorism are changing with regard to the development of technologies and modern methods of communication, the transfer of information, and the achievement of the 
goals of terrorist organizations. While the motives of terrorists may differ, the actions they perpetrate follow a standard pattern of destruction of life, property, and peace. This may take form in different activities including kidnappings, assassinations, threats, bombings, hijacking airplanes, public transportation, and suicide attacks (Boualal, 2017). The intention of each of these types of terrorist activities is to successfully apply enough pressure on governments resulting in granting political concessions to the terrorist or group of terrorists. As stated by Korstanje and Skoll (2013), terrorism is political violence that affects a targeted audience to reach objectives and beliefs of the organization in order to improve their power situation.

The link between terrorism and tourism is almost unbreakable (Bjelajac, 2018, 8). Examples of the bad impact of terrorism on tourism are shown by research on unpleasant events in America, India, France, Greece, Turkey (Sahoo, Jain \& Singh, 2017). During 2003, there were terrorist attacks, the war in Iraq, which had a very bad effect on tourism revenues (UNWTO, 2005). It is an unfortunate fact of the 21st century that deadly terrorism continues to plague nations where tourism is one of the major sources of their economy, as exemplified by both France and Turkey who continue losing this income because of tragic terrorist attacks (Boulal, 2017).

\section{MATERIALS AND METHODS}

In order to analyze the positive effects of Covid19 on the environment, a review of scientific papers and analysis of research results was performed, with the aim of showing whether the slowdown in tourist trends had a positive impact on the environment. The methods used in this paper are methods of analysis and synthesis. The hypothesis that was used in the paper is that the slowdown in tourist movements caused by Covid-19 had a positive effect on the recovery of the environment and the reduction of pollution.

The subject of the research is the state of the environment created under the influence of COVID19, during 2020. The aim of the research is to analyze scientific papers that have dealt with the impact of pandemics on the environment, in order to better understand the consequences that tourist trends have on the living world.

\section{RESULTS AND DISCUSSION}

COVID-19 (coronavirus disease of 2019) stopped the World, as for the last few months millions of people were staying at home in a quarantine (Pawlowski, 2020, 7). That is the reason why the World Tourism Organization (UNWTO) recently announced that tourism is "one of the hardest hit sectors by COVID-19" (www.unwto.org). COVID-19 is devastating hotel industry. Impact COVID-19 to travel industry is 9 times worse than September 11 th, with lost off $\$ 270 \mathrm{~B}$ total (Eight in 10 hotel rooms are empty). 2020 is projected to be the worst year on record for hotel occupancy. Forecasted occupancy rate for 2020 is worse than 1933 during Great Depression (www.ahla.com). About $70 \%$ of hotel employees have been laid off or furloughed. With the impact to the travel industry nine times worse than September 11th, the human toll of this public health crisis has been absolutely devastating for the hotel industry. For the hotel industry our priority is rehiring and retaining our hardworking employees who power our vibrant industry (www.hotelmanagement.net).

The relationship between tourism and sustainable development, as illuminated by the COVID-19 crisis, can be seen in a number of ways. Initially, a number of environmental improvements were identified including marked reductions in pollution levels and greenhouse gas emissions, following the closure of many power generation plants and factories, the dramatic fall in the volume of air travel and the restrictions on the movement of people in motor vehicles (Jones \& Comfort, 2020). The positive effects of COVID-19 on the environment were created by the slowdown of economies, the reduced number of trips imposed by quarantine. Noise caused by air traffic has been identified as one of the main environmental problems and limiting factors for sustainable development (Puharić, Anđelković \& llić, 2020). In this way, constant air pollution and environmental threats are significantly reduced, and the effects can be noticed around the world. The first example of reduced air pollution was observed in the country where it all began, in China. COVID-19 first appeared in December 2019, when due to quarantine the roads were left empty because no one was driving cars anymore. In Wuhan, the locals are amazed to see the clear sky again, because their city is $90 \%$ of the time covered with smog, which is dangerous to health. The sanctions that caused the reduction in travel affected the levels of pollution throughout China. Satellite images made by NASA have shown a constant decline in nitrogen dioxide $\left(\mathrm{NO}_{2}\right)$ in China since the beginning of the New Year (Figure 1). Satellite images from the European Space Agency show reduced levels of pollutants in many large and industrial cities in Europe and Asia than in the same period last year. The recordings showed that around the city of Wuhan, the epicenter of the epidemic, which is also the transport headquarters, as well as the location where many factories are located, and it has a great 
reduction in air pollution. Also, the recordings show that in Italy, especially in the northern part, pollution has dropped, for example only $\mathrm{NO}_{2}$ by as much as $40 \%$. This trend is also noticeable in other cities across Europe, which, under the onslaught of the virus, has begun to introduce measures to reduce movement or ban it, as well as to close industrial plants. Industry, trade, traffic, as well as everyday life are at a standstill, and according to satellite images, this has proved to be the main reason why air pollution has been reduced (Wang \& Su, 2020; Chakraborty \& Maity, 2020; ESA, 2020).

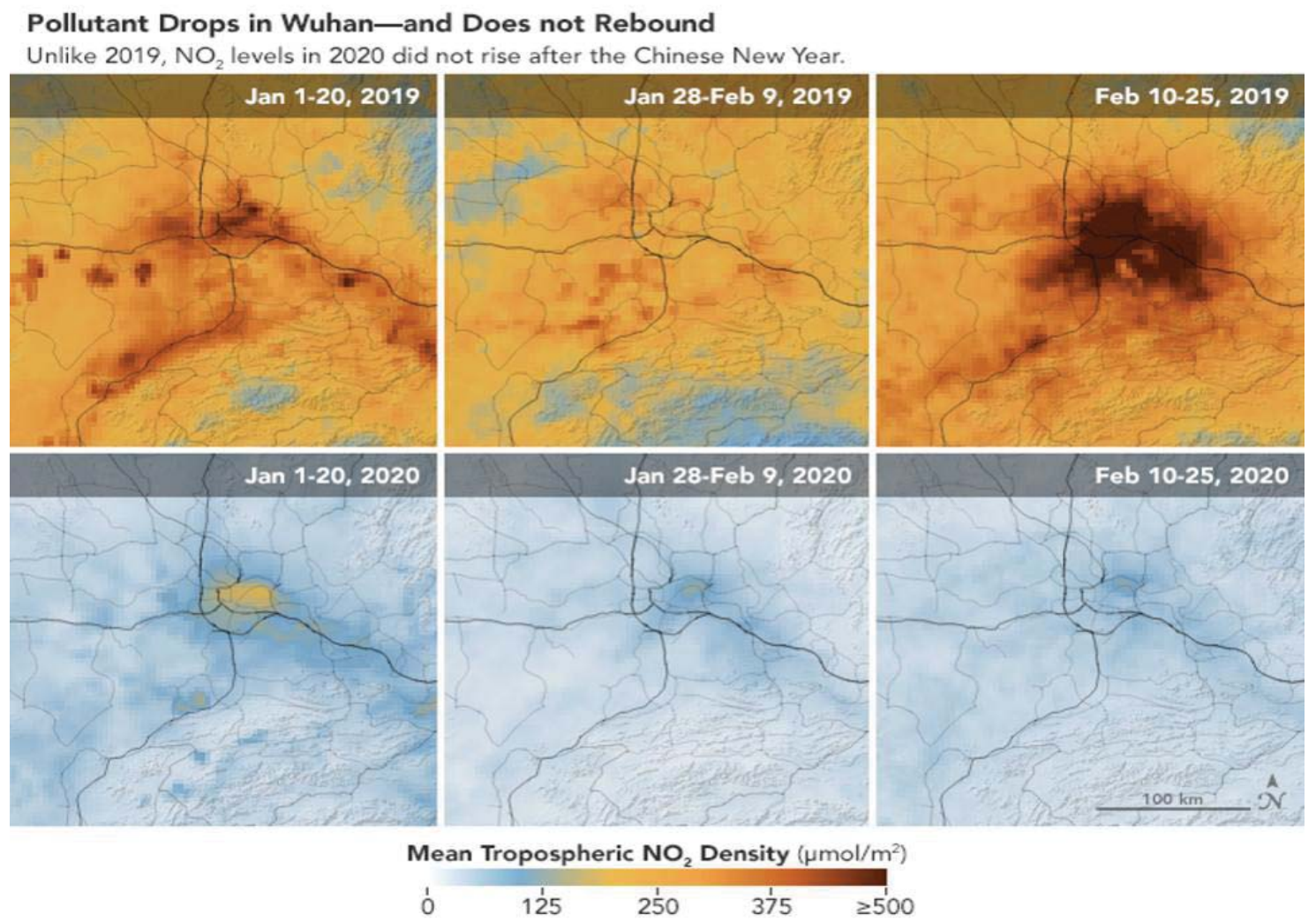

Figure 1 - Pollutant Drops in Wuhan.

Source: earthobservatory.nasa.gov

International flight traffic has been greatly affected, and Hubei province was placed under lockdown approximately 3 weeks after the start of COVID-19 outbreak. In Wuhan, the imposed lockdown resulted in travel restrictions to and from Wuhan to ensure rigorous adherence to home quarantine. Social distancing was practiced by canceling events and gatherings, closing of public places as well as schools and universities. Additionally, outside activities were extremely limited since every citizen was given a permission card and only allowed to leave their home every second day for a maximum of 30 minutes. From previous studies, we know that travel restrictions have demonstrated a positive effect in past SARS, Ebola and bubonic plague outbreaks (Lau et al., 2020; Lai et al., 2020).

As a result, power plants and industrial facilities halted their production. Also, the use of vehicles decreased considerably. All this led to a dramatic reduction in the concentrations of Nitrogen Dioxide $\left(\mathrm{NO}_{2}\right)$ and Particulate Matter that have a diameter of less than $2.5 \mu \mathrm{m}$ (PM 2.5) in the main Chinese cities.

In other parts of the world, such as Europe, air pollution has dramatically reduced since governments ordered citizens to stay at home to contain the spread of the new coronavirus. Main industries as well as other regular activities have ground to a halt. For instance, car use has reduced which caused GHGs to decrease. Figures 2 and 3 clearly illustrates as harp reduction in $\mathrm{NO}_{2}$ concentrations in countries such as France, Italy, Germany (ESA, 2020). The pandemic also affected waterways in Italy. A video recently posted online shows the dramatic transformation of canals in Venice, which have become crystal clear due to a serious decline in tourism. Absence of tourists and significantly reduced river traffic allow fish to swim in clean canals. 


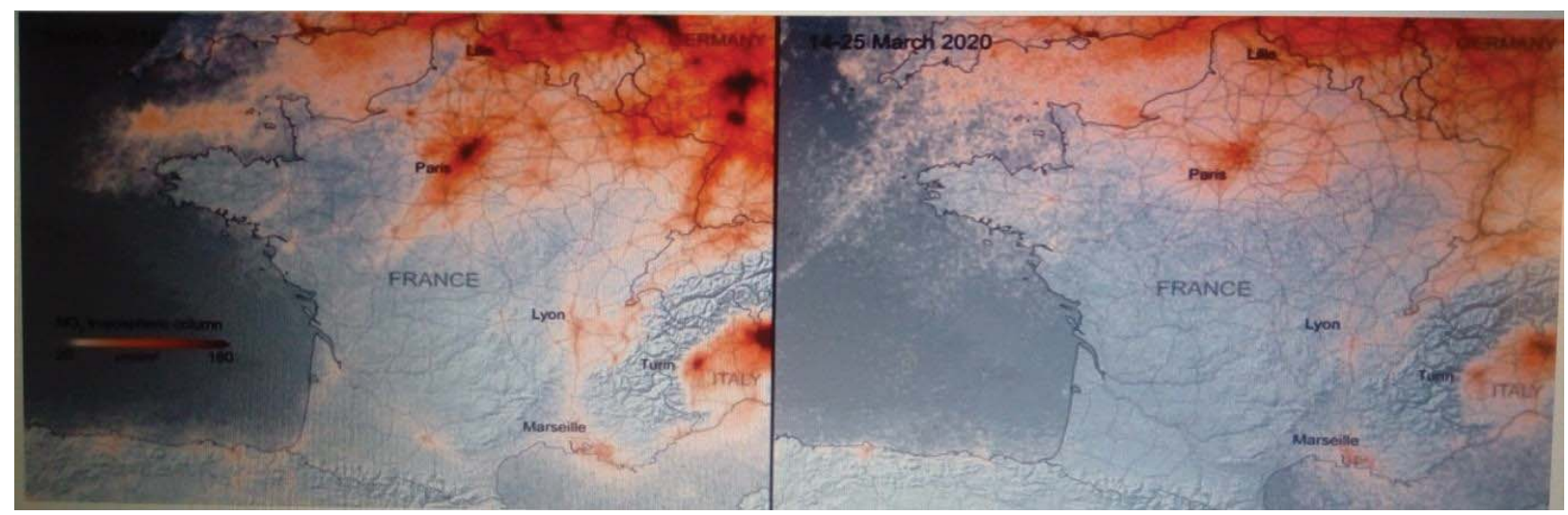

Figure 2 - Air pollution in France and Germany before and after the introduction of measures due to COVID-19 Source: ESA (2020)

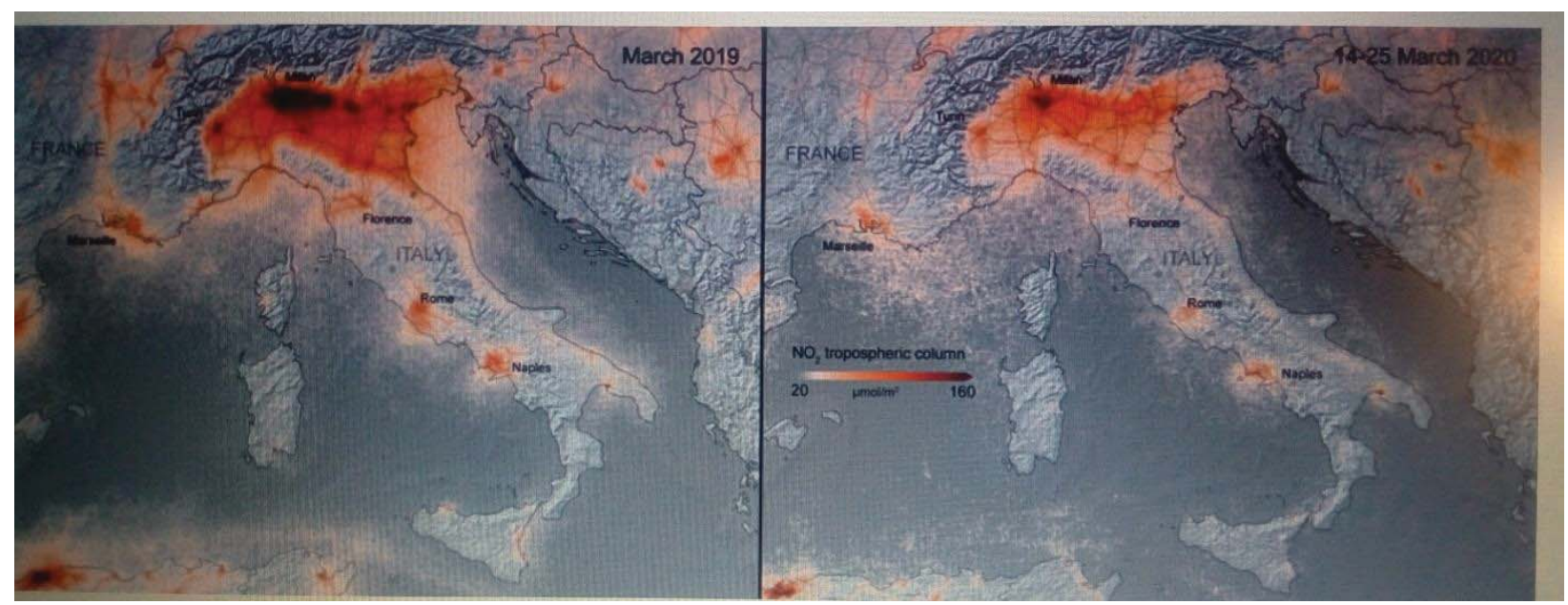

Figure 3 - Air pollution in Italy before and after the introduction of measures due to COVID Source: ESA (2020)

Beaches are one of the most important natural capital assets found in coastal areas (ZambranoMonserrate et al., 2018). They provide services (land, sand, recreation, and tourism) that are critical to the survival of coastal communities and possess intrinsic values that must be protected from overexploitation (Lucrezi et al., 2016). However, nonresponsible use by people has caused many beaches in the world to present pollution problems (Partelow, Wehreden \& Horn, 2015). The lack of tourists, as a result of the social distancing measures due to the new coronavirus pandemic, has caused a notable change in the appearance of many beaches in the world. For example, beaches like those of Acapulco (Mexico), Barcelona (Spain), or Salinas (Ecuador) now look cleaner and with crystal clear waters. Reduction of environmental noise level Environmental noise is defined as an unwanted sound that could be generated by anthropogenic activities (for instance, industrial or commercial activities), the transit of engine vehicles, and melodies at high volume. Environmental noise is one of the main sources of discomfort for the population and the environment, causing health problems and altering the natural conditions of the ecosystems (Zambrano-Monserrate \& Ruano, 2019). The imposition of quarantine measures by most governments has caused people to stay at home, and animals to return to their habitats and walk the streets freely. An example of this is the appearance of dolphins in Venice and hedgehogs, ducks, birds in the center of one of the most polluted cities in Europe, Pančevo. In order to successfully implement the development of sustainable tourism, it is important to form ecotourism offers, which will be based on a healthy environment (Milićević, Đorđević \& Krejić, 2019).

\section{CONCLUSION}

The coronavirus (COVID-19) pandemic has triggered an unprecedented crisis in the tourism economy, given the immediate and immense shock to the sector. Revised OECD estimates on the 
COVID-19 impact point to $60 \%$ decline in international tourism in 2020. Despite that, the positive impact of COVID-19 is maintained on the environment, due to the reduction of pollution, which was also contributed by the reduction of tourist movements. Positive effects are observed due to the change of particles of PM 2.5 and $\mathrm{NO}_{2}$ concentrations in China, France, Germany, Italy, as well as the occurrence of various animal species in those destinations that were highly endangered by tourists, such as Italy, but also air pollution in certain cities in Serbia. Although the virus has had many negative effects on humanity, improving the quality of water, air, soil, and beach cleanliness, are some of the positive effects have resulted from reduced pollution. In order for long-term positive effects on the environment to be visible, it is necessary to reduce pollution in the long run, which also contributes to restrictions on tourist movements, more rational use of natural resources, reduction of flights, exhaust gases and various measures that need to be introduced to preserve environment.

\section{REFERENCES}

All Internet articles were retrieved in June 2020.

[1] Barbhuiya, M.R. \& Chatterjee, D. (2020). Vulnerability and resilience of the tourism sector in India: Effects of natural disasters and internal conflict, Tourism Management Perspectives, 33, p.100616.

[2] Bauman, M.J., Yuang J. \& Williams, H.A. (2019). Developing a measure for assessing tourists' empathy towards natural disasters in the context of wine tourism and the 2017 California wildfires, Current Issues in Tourism, 1-16.

[3] Becken, S. \& Carmignani, F. (2016). Does tourism lead to peace? Annals of Tourism Research, 61, 63-79.

[4] Bjelajac, S. (2018). Uticaj terorizma na turističku potražnju - primjer država članica EU, diplomski rad, Ekonomski fakultet, Sveučilište u Splitu.

[5] Boulal, S. (2017). The Impact of Terrorism on the Economic Sustainable Tourism Development of the Island of Crete, Athens Journal of Tourism, 4(4), 335-353.

[6] Carr, A. (2020). COVID-19, indigenous peoples and tourism: a view from New Zealand, in: Tourism Geographies, 1-12.

[7] Chakraborty, I. \& Maity, P. (2020). COVID-19 outbreak: Migration, effects on society, global environment and prevention, Science of the Total Environment, 138882.
[8] ESA, 2020, http://www.esa.int/Applications/ Observing_the_Earth/Copernicus/Sentinel5P/Coronavirus_lockdown_leading_to_drop_ in_pollution_across_Europe

[9] Fernando, S. (2017). Demand, Volatility and Post-war Tourism in Sri Lanka. Grin Publishing.

[10] Genç, R. (2018). Catastrophe of Environment: The Impact of Natural Disasters on Tourism Industry, Journal of Tourism \& Adventure, 1(1), 86-94.

[11] Han, S. (2019). Topic: Tourism industry in China, Available at: https://www.statista.com/ topics/1210/tourism-industry.

[12] Harb, A., 2016, Impact of War And Terrorism on Tourism and Hospitality Sector in Lebanon, in: Annual of Sofia University St. Kliment Ohridski, 109(2).

[13] Hoque, A., Shikhah, F.A., Hasanat, M.W., Arif, I., \& Hamid, A.B.A. (2020). The effect of Coronavirus (COVID-19) in the tourism industry in China, Asian Journal of Multidisciplinary Studies, 3(1), 52-58.

[14] https://earthobservatory.nasa.gov/images/146 362/airborne-nitrogen-dioxide-plummets-overchina.

[15] https://www.ahla.com/

[16] https://www.hotelmanagement.net/

[17] Jones, P. \& Comfort, D. (2020). The COVID-19 Crisis, Tourism and Sustainable Development. Athens Journal of Tourism, 7(2), 75-86.

[18] Kapiki S. (2012). The impact of economic crisis on tourism and hospitality: results from a study in Greece, Central European Review of Economics and Finance, 2(1), 19-30.

[19] Korstanje, M.E. \& Skoll, G. (2013). Discussing concepts: terrorism and tourism in the spotlight, Turismo y Desarrollo: Revista de Investigación en Turisme y Desarrollo Local, 6 (14).

[20] Krejić, Ž., Čerović, S. \& Milićević, S. (2017). Historical development of tourism in Serbia, Hotel and Tourism Management, 5(1), 55-63.

[21] Lai, C.C., Shih, T.P., Ko, W.C., Tang, H.J. \& Hsueh, P.R. (2020). Severe acute respiratory syndrome coronavirus 2 (SARS-CoV-2) and corona virus disease-2019 (COVID-19): the epidemic and the challenges, International journal of antimicrobial agents, 105924.

[22] Lau, H., Khosrawipour, V., Kochbach, P., Mikolajczyk, A., Schubert, J., Bania, J. \& Khosrawipour, T. (2020). The positive impact of lockdown in Wuhan on containing the COVID-19 outbreak in China, Journal of Travel Medicine, 27(3). 
[23] Lepp, A., Gibson, H. \& Lane, C. (2011), Image and perceived risk: A study of Uganda and its official tourism website, Tourism Management, 32(3), 675-684.

[24] Lucrezi, S., Saayman, M. \& Van Der Merwe, P. (2016). An assessment tool for sandy beaches: A case study for integrating beach description, human dimension, and economic factors to identify priority management issues, Ocean \& Coastal Management, 121, p. 1-22. https://www.oecd.org/

[25] Milićević, S., Đorđević, N. \& Krejić, Ž. (2019), Krupajsko vrelo kao nova eko-turistička destinacija Srbije, Ecologica, 26 (96): 481-486.

[26] Pappas, N. \& Apostolakis, A. (2020), Financial crisis and tourism Activity: Evidence from the UK, In: Destination Management and Marketing: Breakthroughs in Research and Practice (p.784-801). IGI Global.

[27] Partelow, S., Von Wehreden, H. \& Horn, O. (2015). Pollution exposure on marine protected areas: a global assessment, Marine Pollution Bulletin, 100 (1), 352-358.

[28] Pawlowski, A. (2020), Covid-19, Environmental Engineering and the End of the World as We Know it, Problemy Ekorozwoju - Problems of Sustainable Development, 15(2), 7-14.

[29] Puharić, M., Anđelković, M. \& Ilić, I. (2020). Buka generisana vazdušnim saobraćajem, Ecologica, 27(99): 500-506.

[30] Sahoo, B.P., Jain, N. \& Singh, A. (2017), A Study on the Impact of Terrorism on Tourism Sector in India: An Empirical Approach, Asian Journal of Research in Business Economics and Managament, 7(3), 31-36.

[31] Springer, K. (2020), Tourism industry hit hard as Chinese tourists stay home, CNN travel, [online], Available at: https://edition.cnn.com/travel/article/wuhancoronavirus-tourismimpact/index.html.

[32] Tsai, C.H., Wu, T.C., Wall, G. \& Linliu, S.C. (2016), Perceptions of tourism impacts and community resilience to natural disasters, Tourism Geographies, 18(2), 152-173.

[33] United Nations World Tourism Organization (UNWTO), 2005, Tourism Market Trends World Overview and Tourism Topics, Edition.

[34] United Nations World Tourism Organization (UNWTO), 2020, Impact assessment of the COVID-19 outbreak on international tourism. Retrieved from: https://www.unwto.org.

[35] Walters, G., Mair, J. \& Ritchie, B. (2015), Understanding the tourist's response to natural disasters: The case of the 2011 Queensland floods, Journal of Vacation Marketing, 21(1), 101-113.

[36] Wang, Z., Dai, Q., Han, D., Wang, H. \& Huang, J. (2018), Analysis of the Economic Impact of Natural Disasters on Tourism Industry - Case Studies on Cities Threatened by Floods in China, 20th EGU General Assembly, Vienna, p.3431.

[37] Wang, Q. \& Su, M. (2020), A preliminary assessment of the impact of COVID-19 on environment - a case study of China, Science of the Total Environment, 138915.

[38] WHO, 2020.

https://www.who.int/emergencies/diseases/no vel-coronavirus-2019Accessed date: 17 June 2020.

[39] World Travel and Tourism Council, 2019, Tourism as a driver of peace, https://wttc.org/.

[40] Zambrano-Monserrate, M.A., Ruano, M.A. \& Sanchez-Alcalde, L. (2020), Indirect effects of COVID-19 on the environment, Science of the Total Environment, 138813. 